\title{
EFFECT OF DRYING ON COLOR, PROXIMATE COMPOSITION AND DRYING KINETICS OF SLICED CHESTNUTS
}

\author{
TERESA DELGADO ${ }^{1,2}$, JOSÉ ALBERTO PEREIRA ${ }^{1}$, SUSANA CASAL 2,3 and ELSA RAMALHOSA ${ }^{1}$ \\ 'Mountain Research Centre (CIMO) - School of Agriculture, Polytechnic Institute of Bragança, Campus de Sta Apolónia, Apartado 1172, Bragança \\ 5301-855, Portugal \\ ${ }^{2}$ LAQV-REQUIMTE, Faculty of Pharmacy of University of Porto, Rua de Jorge Viterbo Ferreira, n. ${ }^{\circ} 228$, Porto 4050-313, Portugal
}

${ }^{3}$ Corresponding author.
TEL: +351-220428638;
FAX: +351-226093390;
EMAIL: sucasal@ff.up.pt

Received for Publication January 6, 2015 Accepted for Publication May 14, 2015

doi:10.1111/jfpe.12244

\begin{abstract}
In the present work, dried sliced chestnuts (Judia and Longal varieties), product with an increased shelf life, low calorie and gluten-free contents, were prepared. The effect of air convective drying on the drying kinetics, color and proximate composition of sliced chestnuts was evaluated. Even though significant differences in nutritional composition were found between both varieties at the beginning, the drying behaviors were similar; however, Judia dried at a slightly faster rate than Longal. The use of Page, two-term, and modified Henderson and Pabis models fitted well the experimental data (adjusted $R^{2}>0.999$ ). With drying, slight variations in color were observed for both varieties and only moisture content decreased significantly.

The obtained product retained all chemical composition, and due to the low caloric value $(367 \mathrm{kcal} / 100 \mathrm{~g}$ product), low fat and gluten-free contents of chestnut slices, this can be an interesting substitute to other high-calorie snacks available in the market.
\end{abstract}

\section{PRACTICAL APPLICATIONS}

The chestnut fruit is increasingly popular among consumers. The fruit is usually sold fresh or frozen while smaller fruits are generally rejected by industries. So, it is very important to find alternatives to valorize these fruits. Moreover, consumers search for healthy and easy-to-consume food. Chestnut follow these requisites, being a nut with interesting properties due to its low fat content, high levels of starch (sugar of slow absorption) and significant amounts of fibers. Furthermore, it is a gluten-free nut, ideal for celiac patients. On the other hand, the majority of snacks in the market are rich in fat and are made from wheat flour. So, the development of snacks based on chestnut would be innovative. This study intends to provide information on the effect of drying on color, nutritional composition and drying kinetics of sliced chestnut in order to obtain a healthy and low-calorie content snack.

\section{INTRODUCTION}

Consumers' search for healthy and easy-to-consume food is increasing. Chestnut follows these requisites, being a nut with interesting properties due to its low fat content, high levels of starch (sugar of slow absorption) and significant amounts of fibers (Borges et al. 2008). Furthermore, it is a gluten-free nut, ideal for celiac patients. On the other hand, the majority of snacks in the market are rich in fat and are made from wheat flour (that contains gluten). So, the development of snacks based on chestnut would be innovative and will allow the development of new products to persons with sensitivity to gluten. The production of dried slices of chestnuts emerged as a possible and healthy option, with low-calorie content.

Several studies on hot air drying have been performed in chestnuts, namely on drying kinetics (Moreira et al. 2005; Guiné and Fernandes 2006; Cletus and Carson 2008), 
drying characteristics and energy requirement for dehydration (Koyuncu et al. 2004), the effect of drying temperatures on morphological, chemical, thermal and rheological properties in chestnut flours (Correia et al. 2009; Correia and Beirão-da-Costa 2012; Moreira et al. 2013), the effect of drying followed by rehydration on different properties of chestnuts (Attanasio et al. 2004; Moreira et al. 2008, 2011) and how starch is affected by different drying methods (Zhang et al. 2011).

Until now, most of these studies have been carried out with peeled and unpeeled whole fruits. Only one study using prismatic chestnut samples $(10 \times 10 \times 15 \mathrm{~mm})$, subjected to convective air drying at $65 \pm 0.5 \mathrm{C}$ has been performed (Moreira et al. 2011). Still, only the chestnut cellular tissue was analyzed with significant changes in cell size as drying process progressed. So, until now few results exist on the role of drying in sliced chestnuts properties. Thus, the aim of our work was to assess the effect of hot-air convective drying in physical and proximate composition of chestnuts cut in slices along drying time in order to analyze the effect of thermal processing on them.

\section{MATERIALS AND METHODS}

\section{Plant Material}

Two chestnut varieties were used in this study, namely Longal and Judia, the most common in the region. The nuts were acquired directly to chestnut producers of Macedo de Cavaleiros (Longal variety) and Vinhais (Judia variety) at north-east of Portugal (50 kg each variety) in November
2012 and stored in cold chambers $(4 \pm 1 \mathrm{C}$ ) (maximum 1 month) until the analyses were carried out.

\section{Drying Experiments}

After removing carefully the exterior shell with a knife, chestnuts were sliced with approximately $4-6 \mathrm{~mm}$ of thickness (Fig. 1 at $0 \mathrm{~h}$ ). Then, for fixed time periods (1, 2, 4, 6, 8 and $10 \mathrm{~h}$ ), around $150 \mathrm{~g}$ of chestnut slices were dried in a tray dryer (Armfield, Ringwood, England) at 50C (Fig. 2). This temperature was chosen because it was the maximum allowable by the equipment and it was a common temperature found on other drying studies of fruits (Koyuncu et al. 2004; Correia et al. 2009; Correia and Beirão-da-Costa 2012). The tray dryer consisted of one fan and an electric heating element (maximum power $3 \mathrm{~kW}$ ). The hot air passed through the central section of the duct, where the tray with the material to drying is fixed, going out to the atmosphere. The tray was connected to a decimal scale and the data acquisition was recorded in a computer through the Windows Hyperterminal software (Hilgraeve, Monroe, Michigan, USA).

The air velocity was measured with a portable anemometer (Airflow, LCA 6000, Buckinghamshire, England) and kept constant at $1.2 \pm 0.1 \mathrm{~m} / \mathrm{s}$ throughout experiments. The control (fresh chestnuts) and drying samples (1, 2, 4, 6,8 and $10 \mathrm{~h}$ ) were frozen and freeze-dried in order to determine their moisture contents and their proximate composition were expressed in dry basis. All drying experiments at each time period were performed in triplicate.
Varieties $\mathbf{t}=\mathbf{0} \mathbf{h}$

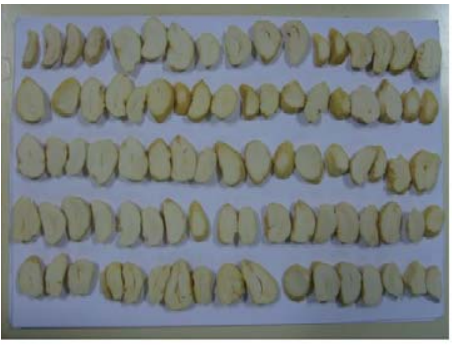

Longal

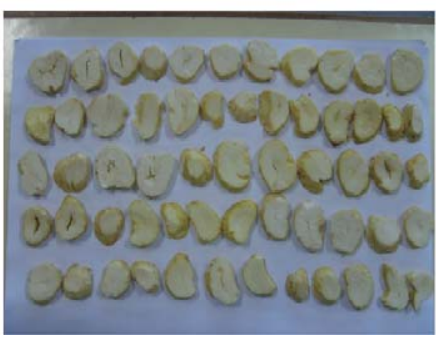

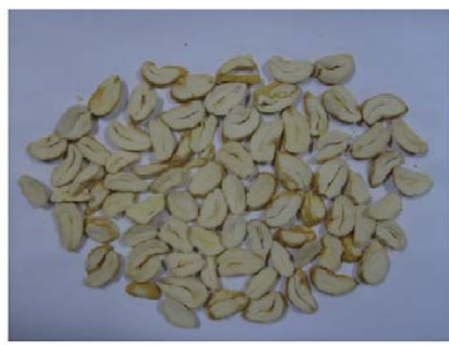

$\mathbf{t}=\mathbf{1 0} \mathrm{h}$

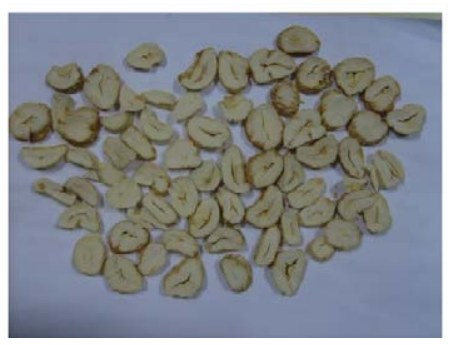

FIG. 1. CHESTNUTS OF LONGAL AND JUDIA VARIETIES AT 0 AND $10 \mathrm{H}$ AFTER DRYING AT $50 \mathrm{C}$ 

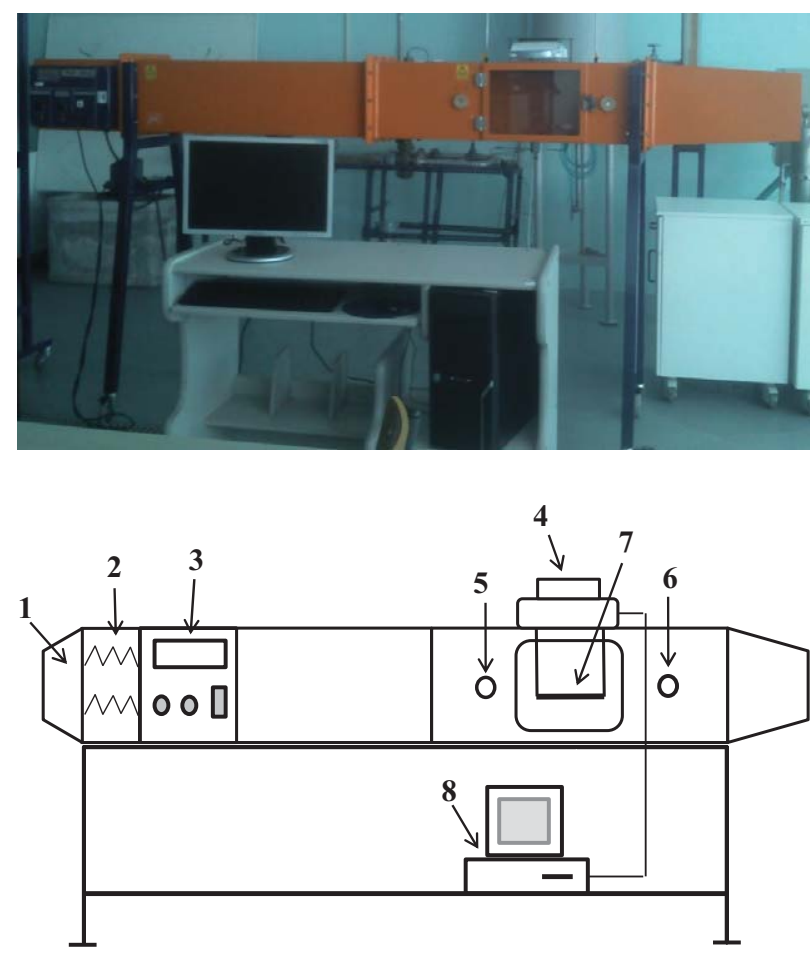

FIG. 2. PHOTOGRAPH AND SCHEMATIC FIGURE OF THE TRAY DRYER (ARMFIELD): FAN (1); HEATER (2); CONTROL PANEL (3); DECIMAL BALANCE (4); TEMPERATURE AND HUMIDITY SENSORS (5) AND (6); TRAY FOR SAMPLES (7); COMPUTER (8)
The drying process was followed by weighting the chestnut slices at regular time intervals (40 s) with an accuracy of $\pm 0.1 \mathrm{~g}$, being the moisture ratios (MR) determined by Eq. (1).

$$
M R=\frac{W-W_{e}}{W_{0}-W_{e}}
$$

where $W, W_{0}$ and $W_{e}$ represent the instantaneous, initial and equilibrium dry basis water contents ( $\mathrm{kg}$ water/kg dry basis), respectively. $W_{e}$ was determined as the asymptotic value of the function fit of the experimental points at the final stage of drying.

Several mathematical models were tested to fit the moisture ratio versus time; however, only the three best models are presented, whose equations are shown in Table 1.

The model parameters were determined by SPSS software (Version No. 20.0, IBM Corporation, Armonk, New York, USA) and the suitability of the fits was evaluated by the following parameters:

$$
\begin{gathered}
S S E=\sum_{i=1}^{n}\left(y_{\exp , i}-y_{\bmod e l, i}\right)^{2} \\
S S T=\sum_{i=1}^{n}\left(y_{\exp }-y_{\text {average }}\right)^{2} \\
R^{2}=1-\frac{S S E}{S S T}
\end{gathered}
$$

\begin{tabular}{|c|c|c|c|}
\hline Variety & $\begin{array}{l}\text { Page model } \\
M R=\exp \left(-k \times t^{n}\right)\end{array}$ & $\begin{array}{l}\text { Two-term model } \\
M R=a \times \exp (-k \times t)+b \times \exp (-g \times t)\end{array}$ & $\begin{array}{l}\text { Modified Henderson and Pabis model } \\
M R=a \times \exp (-k \times t)+b \times \exp (-g \times t)+c \times \exp (-h \times t)\end{array}$ \\
\hline Judia & $\begin{array}{l}k=0.3727 \\
n=0.8973 \\
\text { SSE: } 0.02617 \\
R^{2}: 0.9995 \\
\text { Adjusted } R^{2}: 0.9995 \\
\text { RMSE: } 0.00540\end{array}$ & $\begin{array}{l}a=0.115 \\
k=2.566 \\
b=0.8972 \\
g=0.2925 \\
\text { SSE: } 0.00343 \\
R^{2}: 0.9999 \\
\text { Adjusted } R^{2}: 0.9999 \\
\text { RMSE: } 0.001956\end{array}$ & $\begin{array}{l}a=0.8977 \\
b=0.5535 \\
c=-0.4393 \\
g=2.286 \\
h=2.217 \\
k=0.2926 \\
S S E: 0.00346 \\
R^{2}: 0.9999 \\
\text { Adjusted } R^{2}: 0.9999 \\
\text { RMSE: } 0.00197\end{array}$ \\
\hline Longal & $\begin{array}{l}k=0.3462 \\
n=0.8452 \\
\text { SSE: } 0.03826 \\
R^{2}: 0.9992 \\
\text { Adjusted } R^{2}: 0.9992 \\
\text { RMSE: } 0.00652\end{array}$ & $\begin{array}{l}a=0.8619 \\
k=0.237 \\
b=0.1446 \\
g=2.218 \\
\text { SSE: } 0.00164 \\
R^{2}: 1.000 \\
\text { Adjusted } R^{2}: 1.000 \\
\text { RMSE: } 0.00135\end{array}$ & $\begin{array}{l}a=0.2803 \\
b=0.5799 \\
c=0.1469 \\
g=0.2363 \\
h=2.189 \\
k=0.2363 \\
\text { SSE: } 0.00104 \\
R^{2}: 1.000 \\
\text { Adjusted } R^{2}: 1.000 \\
\text { RMSE: } 0.00108\end{array}$ \\
\hline
\end{tabular}

TABLE 1. DRYING CURVE MODELS AT 50C FOR TWO CHESTNUT VARIETIES

RMSE, calculated by Equation (6); SSE, calculated by Equation (2). 


$$
\begin{gathered}
R^{2} \text { adj }=1-\frac{S S E \times(n-1)}{S S T \times v} \text { where } v=n-m \\
R M S E=\sqrt{\frac{S S E}{v}}
\end{gathered}
$$

where $y_{\text {exp,i }}$ and $y_{\text {model, } i}$ are the experimental and predicted values for the $i$ observation, respectively, $n$ is the number of observations and $m$ is the number of parameters in each model (Yaldýz and Ertekýn 2001; Togrul and Pehlivan 2003).

\section{Physicochemical Characterization}

Color. The color of chestnut slices was determined during the drying experiments by a Minolta CR- 400 colorimeter in CIELab color space, through the coordinates: $L^{*}, a^{*}$ and $b^{*}$, using the Spectra Magic Nx software (version CM-S100W 2.03.0006, Konica Minolta Company, Osaka, Japan) described in a previous study (Delgado et al. 2014). The $C^{*}$ (chroma or saturation) and $h^{*}$ (hue angle) were also calculated by the following equations:

$$
\begin{aligned}
& C^{\star}=\sqrt{a^{\star 2}+b^{\star 2}} \\
& h^{\star}=\arctan \left(\frac{b^{\star}}{a^{\star}}\right)
\end{aligned}
$$

chroma $\left(C^{\star}\right)$ measures the purity or saturation of the color, while hue $\left(h^{\star}\right)$ denotes the subtle distinction or variation in color (Rajasekar et al. 2012). In order to analyze the changes on color along the drying process, this parameter was determined at the beginning (color of fresh chestnut, considered as reference) and after the drying process on 60 slices. So, the $\Delta L^{*}, \Delta a^{*}, \Delta b^{*}, \Delta C^{*}$ and $\Delta h^{*}$ were determined by the difference of the values at the end and the beginning of the drying process. Moreover, the total color difference $\left(\Delta E^{*}\right)$ was also calculated according to

$$
\Delta E^{\star}=\sqrt{\left(\Delta L^{\star}\right)^{2}+\left(\Delta a^{\star}\right)^{2}+\left(\Delta b^{\star}\right)^{2}}
$$

\section{Proximate Composition}

The samples were analyzed for proximate composition (moisture, proteins, fat and ash) using Association of Official Analytical Chemists (AOAC) procedures (AOAC 1995). All reagents were of analytical grade and purchased from Sigma-Aldrich Chemical Co. (St Louis, MO). Crude protein content of the samples was estimated by the macroKjeldahl method (VELP SCIENTIFICA, Usmate Velate, Italy), using a conversion factor of 5.3 (Borges et al. 2008; Mendes de Vasconcelos et al. 2009); crude fat was determined by extracting $5 \mathrm{~g}$ of sample with petroleum ether for $24 \mathrm{~h}$, using a Soxhlet apparatus (P Selecta, Abrera, Barcelona,
Spain) and ash content was determined by incineration at 550C (Lenton Thermal Designs Ltd, Hope Valley, UK) for $4 \mathrm{~h}$. Neutral detergent fiber (NDF) and acid detergent fiber (ADF) were determined by the method described by Goering and Van Soest (1970). Total carbohydrates were calculated by difference as described by FAO (2003). Total energy was calculated according to Atwater system. All determinations were made in duplicate, comprising six values for each drying treatment performed in triplicate.

\section{Statistical Methods}

The statistical analysis was performed on SPSS software (Version No. 20.0). Comparisons were carried out at 95\% confidence by application of analysis of variance and when significant differences between samples were observed, the Tukey's Honestly Significant Difference test (Tukey's HSD post hoc) was applied.

\section{RESULTS AND DISCUSSION}

\section{Drying Kinetics}

The drying curves of the two chestnut varieties, previously cut in slices, are shown in Fig. 3. These curves are typical drying curves with two phases. At the beginning the drying rate decreased rapidly, followed by a slowly decrease. Both varieties showed similar behaviors along the drying time. Small differences were detected on the initial phase, probably due to their different initial moisture contents, having Judia higher moisture content (52.7\%) than Longal variety (48.5\%) (Fig. 3A). However, by analyzing Fig. 3B we can see that to reach the same moisture ratio (e.g., 0.20 ), the Judia variety lost water more easily than Longal, since a shorter period of time was needed (around $5 \mathrm{~h}$ ) for the former, while Longal needed a little longer than $6 \mathrm{~h}$ to achieve the same value.

Three different mathematical models, namely Page (with one exponential), two-term (with two exponentials) and modified Henderson and Pabis (with three exponentials) models were tested to describe the behavior of chestnuts along drying. The model parameters and the statistics used to evaluate the models suitability are presented in Table 1. It was found that all models described well the experimental data. From the statistical parameters calculated, it was observed that the quality of the fit was good for both chestnut varieties subjected to drying (Table 1), with $R^{2}$ and adjusted $R^{2}$ in the range of 0.9992 to 1 . As all values were near 1 , these models described very well the experimental data. SSE and RMSE also presented low values (close to zero, as desired), varying between 0.00104 to 0.0383 and 0.00108 to 0.00652 , respectively. In general terms, after observing the statistical parameters of the three models, a 

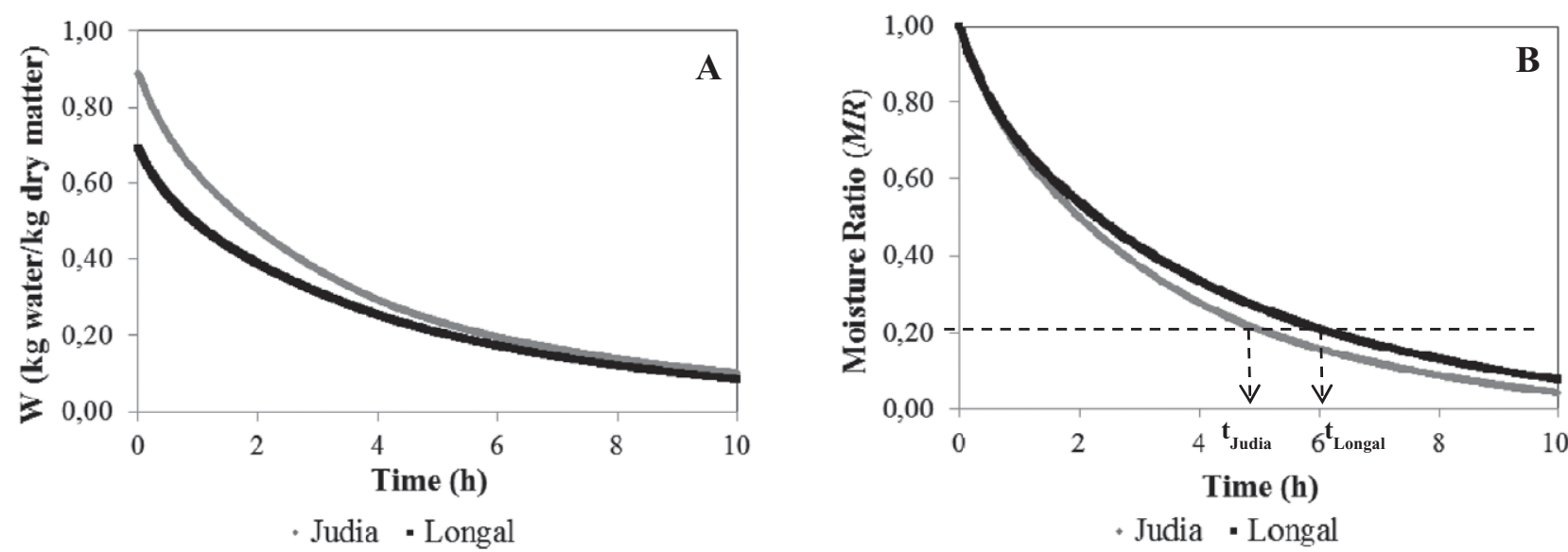

FIG. 3. DRYING RATES IN TERMS OF MOISTURE CONTENT (A) AND MOISTURE RATIO (B) ALONG DRYING TIME FOR LONGAL AND JUDIA VARIETIES

slight improvement was obtained when using two exponential terms compared with Page model with a single exponential. However, with this simple model, good results were obtained. So, this model may be used in the future to predict very satisfactorily the drying curves of chestnut slices.

\section{Effect of Hot-Air Convective Drying on Sliced Chestnut Color}

Color is a highly appreciated property by chestnut consumers. Thus, it is important to analyze the effect of drying in this physical characteristic. The results concerning the color changes throughout drying time are detailed in Table 2. Significant interactions between variety and drying time were always observed $(P<0.001)$.

An increase in $\Delta L^{*}$ absolute values was observed along drying until $4 \mathrm{~h}$ for Longal and $6 \mathrm{~h}$ for Judia varieties. After this period, the values remained almost constant. Moreira et al. (2005) observed a decrease on this parameter when analyzing the $L^{\star}$ values of peeled and cut chestnuts after drying at 45,55 and $65 \mathrm{C}$ in line with that observed in the present work. In our study, a decrease in the $L^{\star}$ values was

TABLE 2. COLOR PARAMETERS ALONG AIR CONVECTION DRYING AT 5OC FOR TWO CHESTNUT VARIETIES, LONGAL AND JUDIA

\begin{tabular}{|c|c|c|c|c|c|c|c|}
\hline \multirow[b]{2}{*}{ Parameter } & \multicolumn{6}{|c|}{ Air convection drying } & \multirow{2}{*}{$\begin{array}{c}P \\
\text { Variety } \times \text { Time }\end{array}$} \\
\hline & $\mathrm{t}=1 \mathrm{~h}$ & $t=2 h$ & $\mathrm{t}=4 \mathrm{~h}$ & $t=6 h$ & $t=8 \mathrm{~h}$ & $\mathrm{t}=10 \mathrm{~h}$ & \\
\hline \multicolumn{8}{|l|}{$\Delta L^{*}$} \\
\hline Longal & $-1.64 \pm 3.34^{c, A}$ & $-3.11 \pm 4.69^{\mathrm{b}, \mathrm{A}}$ & $-5.22 \pm 5.70^{\mathrm{a}, \mathrm{A}}$ & $-4.70 \pm 4.84^{\mathrm{a}, \mathrm{A}}$ & $-5.21 \pm 3.97^{\mathrm{a}, \mathrm{A}}$ & $-4.16 \pm 4.27^{\mathrm{a}, \mathrm{b}, \mathrm{A}}$ & $<0.001$ \\
\hline Judia & $-1.59 \pm 3.29^{c, A}$ & $-2.44 \pm 3.21^{\mathrm{C}, \mathrm{A}}$ & $-3.76 \pm 3.92^{b, B}$ & $-5.32 \pm 4.04^{\mathrm{a}, \mathrm{A}}$ & $-4.84 \pm 5.01^{\mathrm{a}, \mathrm{b}, \mathrm{A}}$ & $-5.81 \pm 4.13^{\mathrm{a}, \mathrm{B}}$ & \\
\hline \multicolumn{8}{|l|}{$\Delta a^{*}$} \\
\hline Longal & $0.56 \pm 0.74^{\mathrm{a}, \mathrm{A}}$ & $0.72 \pm 0.91^{a, b, A}$ & $0.92 \pm 1.53^{b, c, A}$ & $1.39 \pm 1.00^{\mathrm{d}, \mathrm{A}}$ & $1.13 \pm 1.09^{c, d, A}$ & $1.19 \pm 0.85^{c, d, A}$ & $<0.001$ \\
\hline Judia & $0.53 \pm 0.90^{\mathrm{a}, \mathrm{A}}$ & $0.64 \pm 0.92^{\mathrm{a}, \mathrm{b}, \mathrm{A}}$ & $0.88 \pm 0.97^{b, c, A}$ & $0.86 \pm 1.08^{b, c, B}$ & $1.16 \pm 0.95^{\mathrm{c}, \mathrm{d}, \mathrm{A}}$ & $1.34 \pm 0.78^{\mathrm{d}, \mathrm{A}}$ & \\
\hline \multicolumn{8}{|l|}{$\Delta b^{*}$} \\
\hline Longal & $-0.54 \pm 4.28^{\mathrm{a}, \mathrm{b}, \mathrm{A}}$ & $0.46 \pm 4.33^{\mathrm{b}, \mathrm{A}}$ & $0.30 \pm 5.65^{\mathrm{b}, \mathrm{A}}$ & $-1.54 \pm 4.62^{\mathrm{a}, \mathrm{A}}$ & $-0.08 \pm 4.16^{\mathrm{a}, \mathrm{b}, \mathrm{A}}$ & $-1.44 \pm 4.55^{\mathrm{a}, \mathrm{A}}$ & $<0.001$ \\
\hline Judia & $0.39 \pm 4.38^{\mathrm{b}, c, \mathrm{~A}}$ & $-0.04 \pm 5.01^{b, c, A}$ & $-0.64 \pm 4.54^{\mathrm{a}, \mathrm{b}, \mathrm{b}, \mathrm{A}}$ & $0.75 \pm 5.299^{c, B}$ & $-1.00 \pm 5.13^{\mathrm{a}, \mathrm{b}, \mathrm{A}}$ & $-1.56 \pm 4.17^{\mathrm{a}, \mathrm{A}}$ & \\
\hline \multicolumn{8}{|l|}{$\Delta C^{*}$} \\
\hline Longal & $-0.59 \pm 4.30^{a, b, c, A}$ & $0.40 \pm 4.34^{\mathrm{c}, \mathrm{A}}$ & $0.25 \pm 5.65^{\mathrm{c}, \mathrm{A}}$ & $-1.66 \pm 4.62^{\mathrm{a}, \mathrm{A}}$ & $-0.17 \pm 4.19^{\mathrm{b}, \mathrm{c}, \mathrm{A}}$ & $-1.54 \pm 4.58^{\mathrm{a}, \mathrm{b}, \mathrm{A}}$ & $<0.001$ \\
\hline Judia & $0.34 \pm 4.41^{b, c, A}$ & $-0.10 \pm 5.03^{b, c, A}$ & $-0.72 \pm 4.57^{a, b, c, A}$ & $0.68 \pm 5.31^{c, B}$ & $-1.09 \pm 5.14^{\mathrm{a}, \mathrm{b}, \mathrm{A}}$ & $-1.66 \pm 4.18^{\mathrm{a}, \mathrm{A}}$ & \\
\hline \multicolumn{8}{|l|}{$\Delta h^{\star}$} \\
\hline Longal & $-1.31 \pm 1.56^{c, A}$ & $-1.88 \pm 2.08^{\mathrm{b}, \mathrm{c}, \mathrm{A}}$ & $-2.39 \pm 4.05^{\mathrm{a}, \mathrm{b}, \mathrm{A}}$ & $-3.20 \pm 2.36^{\mathrm{a}, \mathrm{A}}$ & $-2.91 \pm 2.49^{\mathrm{a}, \mathrm{A}}$ & $-2.67 \pm 1.83^{\mathrm{a}, \mathrm{b}, \mathrm{A}}$ & $<0.001$ \\
\hline Judia & $-1.33 \pm 1.69^{\mathrm{d}, \mathrm{A}}$ & $-1.52 \pm 1.87^{c, d, A}$ & $-2.05 \pm 1.84^{b, c, A}$ & $-1.98 \pm 2.02^{\mathrm{b}, \mathrm{c}, \mathrm{B}}$ & $-2.47 \pm 2.06^{\mathrm{a}, \mathrm{b}, \mathrm{A}}$ & $-3.01 \pm 1.91^{\mathrm{a}, \mathrm{A}}$ & \\
\hline \multicolumn{8}{|l|}{$\Delta E^{\star}$} \\
\hline Longal & $5.02 \pm 2.82^{\mathrm{a}, \mathrm{A}}$ & $5.93 \pm 4.09^{a, b, A}$ & $8.10 \pm 5.41^{\mathrm{d}, \mathrm{A}}$ & $7.58 \pm 3.82^{\mathrm{c}, \mathrm{d}, \mathrm{A}}$ & $6.80 \pm 4.05^{\mathrm{b}, \mathrm{c}, \mathrm{A}}$ & $6.99 \pm 3.37^{b, c, d, A}$ & $<0.001$ \\
\hline Judia & $4.83 \pm 3.20^{\mathrm{a}, \mathrm{A}}$ & $5.69 \pm 3.18^{\mathrm{a}, \mathrm{b}, \mathrm{A}}$ & $6.42 \pm 3.29^{\mathrm{b}, \mathrm{B}}$ & $7.84 \pm 3.72^{\mathrm{c}, \mathrm{A}}$ & $7.97 \pm 3.78^{\mathrm{c}, \mathrm{B}}$ & $7.83 \pm 3.41^{\mathrm{C}, \mathrm{B}}$ & \\
\hline
\end{tabular}

Mean \pm standard devaition with different small letter $(a-d)$ superscripts on the same row are significantly different $(P<0.05)$. Mean \pm standard deviation with different capital letter $(A-B)$ superscripts on the same column are significantly different $(P<0.05)$. 
also detected, explaining the negative values obtained for the $\Delta L^{*}$ (Table 2). Moreover, in the present work, differences between varieties were observed at the beginning $(0 \mathrm{~h})$ (87.3 for Longal and 86.5 for Judia varieties) and after 6 or more hours of drying. Judia always showed lower $L^{*}$ values than Longal (data not shown), indicative of lower lightness.

There was also a significant increase in $\Delta a^{\star}$ values (which indicates higher red proportions) along drying for both varieties. For Longal variety, the $\Delta a^{\star}$ values remained constant after $6 \mathrm{~h}$, while for Judia the $\Delta a^{\star}$ values kept on constant after $8 \mathrm{~h}$. Moreira et al. (2005) also observed an increase in $a^{*}$ values of both peeled and cut chestnuts after drying at 45,55 and $65 \mathrm{C}$.

Regarding $\Delta b^{\star}$ and $\Delta C^{\star}$ parameters, slight variations were observed along drying for both varieties. For Longal variety, after $10 \mathrm{~h}$ of drying, the yellowness variation $\left(\Delta b^{*}\right.$ value) and chroma variation $\left(\Delta C^{\star}\right)$ were not significantly different to $1 \mathrm{~h}$ of drying. On contrary, a significant difference was observed for Judia.

Regarding the hue $\left(h^{*}\right)$ values, both varieties presented a yellow predominant color $\left(h^{*}\right.$ values around $\left.90^{\circ}\right)$ in line with the higher effect of $b^{\star}$ component than $a^{\star}$, due to the higher values of the former (data not shown). However, along drying time, the variation increased in absolute terms for both varieties.

Total color differences $\left(\Delta E^{*}\right)$ were evaluated along drying and values higher than zero were always observed, suggesting that chestnuts color changed along dehydration; however, this variation did not result in a different color because $\Delta E^{\star}$ values were less than 12 (Cecchini et al. 2011) (Fig. 1). For Longal variety, the highest variation on $\Delta E^{*}$ values was observed at $4 \mathrm{~h}$ of drying, remaining almost constant after that time. For Judia, a more constant increase in this parameter was observed, remaining stable after $6 \mathrm{~h}$. These results may be related to the occurrence of enzymatic browning reactions due to polyphenol oxidase activity during drying, as well as to nonenzymatic browning reactions, namely Maillard and caramelization reactions. In fact, Judia variety presents slight higher values of sugars and proteins than Longal that may favor the occurrence of such reactions, as explained subsequently, and supported by the increased redness $\left(a^{*}\right)$, typical color of these browning products.

\section{Effect of the Hot-Air Convective Drying on Sliced Chestnut Proximate Composition}

The results obtained for proximate composition of the two chestnut cultivars along the drying time are shown in Table 3. In almost all situations, significant interactions between variety and drying time were observed $(P<0.05)$, except for crude protein and NDF. However, for these parameters the individual effects of chestnut variety and/or drying time were significant.

Water is the predominant component in fresh chestnuts $(0 \mathrm{~h})$, responsible for its high perishability. Significant differences on moisture contents were found between both varieties, with a mean of $48.5 \pm 0.4 \mathrm{~g} / 100 \mathrm{~g}$ fresh weight for Longal and $52.7 \pm 1.4 \mathrm{~g} / 100 \mathrm{~g}$ fresh weigh for Judia. These results were in accordance with the Spanish and Portuguese cultivars analyzed by Míguelez et al. (2004) (48.37 to $59.35 \mathrm{~g} / 100 \mathrm{~g}$ fresh weight), Pereira-Lorenzo et al. (2006) (40.3 to $60.1 \mathrm{~g} / 100 \mathrm{~g}$ fresh weight), Borges et al. (2008) (46.3 to $53.3 \mathrm{~g} / 100 \mathrm{~g}$ fresh weight) and Correia et al. (2009) (47.9 to $48.2 \mathrm{~g} / 100 \mathrm{~g}$ fresh weight). As expected, the moisture contents decreased along drying and stabilized without significant variations after $8 \mathrm{~h}$ for Longal and $6 \mathrm{~h}$ for Judia. When comparing both varieties, the significant differences observed at the beginning $(0 \mathrm{~h})$ disappeared, supported by a higher moisture loss in Judia, confirming the differences on drying kinetics referred previously.

Significant differences were always found in ash content between the two varieties, with an average of $1.76 \pm 0.02 \mathrm{~g}$ ash/100 g dry weight for Longal and $2.25 \pm 0.12 \mathrm{~g}$ ash/100 $\mathrm{g}$ dry weight for Judia at the beginning of the drying experiments $(0 \mathrm{~h})$. The differences between varieties may be related to genetic differences, altitude and soil type, among others, as proposed by Pereira-Lorenzo et al. (2006). In fact both varieties were from different locations; however, our values are in agreement with Ertürk et al. (2006) (1.02 to $3.22 \mathrm{~g}$ ash/100 g dry weight), Pereira-Lorenzo et al. (2006) (1.8 to $3.2 \mathrm{~g}$ ash/100 g dry weight), Borges et al. (2008) (1.60 to $2.20 \mathrm{~g}$ ash/100 g dry weight) and Correia et al. (2009) (1.9 to $2.1 \mathrm{~g}$ ash/100 g dry weight). Small variations were observed in Longal along drying, while no significant variations were observed in Judia variety. This was expected as this property is not predictable to vary along dehydration.

The fat content in chestnuts is low, but still significantly higher in Longal $(3.26 \pm 0.11 \mathrm{~g}$ fat $/ 100 \mathrm{~g}$ dry weight) than Judia $(2.77 \pm 0.45 \mathrm{~g}$ fat/100 g dry weight) before drying. These values are similar to previous studies such as Ertürk et al. (2006) (0.49 to $2.01 \mathrm{~g}$ fat/100 g dry weight), Pereira-Lorenzo et al. (2006) (1.7 to $4.0 \mathrm{~g}$ fat/100 g dry weight), Borges et al. (2008) (1.73 to $3.10 \mathrm{~g}$ fat/100 g dry weight) and Correia et al. (2009) (2.6 to $3.0 \mathrm{~g}$ fat/100 g dry weight) for Turkish, Spanish and Portuguese varieties. Along drying, the two varieties presented a similar fat content. Furthermore, the fat values determined at the beginning and after $10 \mathrm{~h}$ of the drying process were not significantly different, indicating that this parameter was almost unaffected by the thermal process.

Crude protein did not show significant differences along drying time but differed between the two chestnut varieties. At the beginning, Longal and Judia varieties presented crude 
TABLE 3. MOISTURE CONTENT AND NUTRITIONAL COMPOSITION ALONG AIR CONVECTION DRYING FOR TWO CHESTNUT VARIETIES, LONGAL AND JUDIA

\begin{tabular}{|c|c|c|c|c|c|c|c|c|}
\hline \multirow[b]{2}{*}{ Parameter } & \multicolumn{7}{|c|}{ Air convection drying } & \multirow{2}{*}{$\begin{array}{c}P \\
\text { Variety } \times \operatorname{Tim}\end{array}$} \\
\hline & $t=0 h$ & $t=1 h$ & $t=2 h$ & $\mathrm{t}=4 \mathrm{~h}$ & $t=6 h$ & $t=8 \mathrm{~h}$ & $\mathrm{t}=10 \mathrm{~h}$ & \\
\hline \multicolumn{9}{|c|}{ Moisture ( $\mathrm{g}$ water $/ 100 \mathrm{~g}$ chestnut after drying) } \\
\hline Longal & $48.5 \pm 0.4^{f, A}$ & $36.7 \pm 3.1^{\mathrm{e}, \mathrm{A}}$ & $30.8 \pm 2.9^{\mathrm{d}, \mathrm{A}}$ & $17.3 \pm 1.5^{\mathrm{c}, \mathrm{A}}$ & $16.6 \pm 1.9^{b, c, A}$ & $11.8 \pm 0.7^{\mathrm{a}, \mathrm{b}, \mathrm{A}}$ & $11.0 \pm 0.5^{\mathrm{a}, \mathrm{A}}$ & \multirow[t]{2}{*}{0.013} \\
\hline Judia & $52.7 \pm 1.4^{\mathrm{e}, \mathrm{B}}$ & $38.9 \pm 3.6^{\mathrm{d}, \mathrm{A}}$ & $32.0 \pm 1.5^{c, A}$ & $17.6 \pm 3.0^{\mathrm{b}, \mathrm{A}}$ & $11.5 \pm 0.8^{\mathrm{a}, \mathrm{B}}$ & $11.4 \pm 1.3^{\mathrm{a}, \mathrm{A}}$ & $10.3 \pm 0.2^{\mathrm{a}, \mathrm{A}}$ & \\
\hline \multicolumn{9}{|c|}{ Total ash (g ash/100g dry weight) } \\
\hline Longal & $1.76 \pm 0.02^{\mathrm{b}, \mathrm{c}, \mathrm{A}}$ & $1.78 \pm 0.03^{\mathrm{c}, \mathrm{A}}$ & $1.71 \pm 0.03^{\mathrm{a}, \mathrm{b}, \mathrm{A}}$ & $1.68 \pm 0.03^{\mathrm{a}, \mathrm{A}}$ & $1.78 \pm 0.05^{\mathrm{c}, \mathrm{A}}$ & $1.78 \pm 0.02^{c, A}$ & $1.76 \pm 0.04^{b, c, A}$ & \multirow[t]{2}{*}{0.012} \\
\hline Judia & $2.25 \pm 0.12^{\mathrm{a}, \mathrm{B}}$ & $2.25 \pm 0.05^{\mathrm{a}, \mathrm{B}}$ & $2.26 \pm 0.08^{\mathrm{a}, \mathrm{B}}$ & $2.35 \pm 0.15^{\mathrm{a}, \mathrm{B}}$ & $2.35 \pm 0.07^{\mathrm{a}, \mathrm{B}}$ & $2.30 \pm 0.06^{\mathrm{a}, \mathrm{B}}$ & $2.24 \pm 0.07^{\mathrm{a}, \mathrm{B}}$ & \\
\hline \multicolumn{9}{|c|}{ Crude fat (g fat/100g dry weight) } \\
\hline Longal & $3.26 \pm 0.11^{c, A}$ & $2.78 \pm 0.40^{\mathrm{a}, \mathrm{A}}$ & $2.81 \pm 0.12^{\mathrm{a}, \mathrm{A}}$ & $3.17 \pm 0.08^{b, c, A}$ & $2.66 \pm 0.15^{\mathrm{a}, \mathrm{A}}$ & $2.83 \pm 0.16^{a, b, A}$ & $2.98 \pm 0.15^{\mathrm{a}, \mathrm{b}, \mathrm{c}, \mathrm{A}}$ & \multirow[t]{2}{*}{0.012} \\
\hline Judia & $2.77 \pm 0.45^{\mathrm{a}, \mathrm{B}}$ & $2.69 \pm 0.41^{\mathrm{a}, \mathrm{A}}$ & $2.77 \pm 0.24^{\mathrm{a}, \mathrm{A}}$ & $2.48 \pm 0.32^{\mathrm{a}, \mathrm{B}}$ & $2.50 \pm 0.11^{\mathrm{a}, \mathrm{A}}$ & $2.71 \pm 0.33^{\mathrm{a}, \mathrm{A}}$ & $3.00 \pm 0.19^{\mathrm{a}, \mathrm{A}}$ & \\
\hline \multicolumn{9}{|c|}{ Crude protein (g protein $/ 100 \mathrm{~g}$ dry weight) } \\
\hline Longal & $3.97 \pm 0.20^{\mathrm{a}, \mathrm{A}}$ & $4.81 \pm 0.15^{\mathrm{a}, \mathrm{A}}$ & $4.20 \pm 0.32^{\mathrm{a}, \mathrm{A}}$ & $4.37 \pm 0.12^{\mathrm{a}, \mathrm{A}}$ & $4.42 \pm 0.38^{\mathrm{a}, \mathrm{A}}$ & $4.34 \pm 0.52^{\mathrm{a}, \mathrm{A}}$ & $4.68 \pm 0.28^{\mathrm{a}, \mathrm{A}}$ & \multirow[t]{2}{*}{0.156} \\
\hline Judia & $5.43 \pm 0.46^{\mathrm{a}, \mathrm{B}}$ & $5.41 \pm 0.42^{\mathrm{a}, \mathrm{A}}$ & $5.44 \pm 0.30^{\mathrm{a}, \mathrm{B}}$ & $5.29 \pm 0.65^{a, B}$ & $5.87 \pm 0.30^{\mathrm{a}, \mathrm{B}}$ & $5.59 \pm 0.53^{\mathrm{a}, \mathrm{B}}$ & $5.09 \pm 0.03^{\mathrm{a}, \mathrm{A}}$ & \\
\hline \multicolumn{9}{|c|}{ NDF (g NDF/100g dry weight) } \\
\hline Longal & $9.74 \pm 1.57^{\mathrm{a}, \mathrm{A}}$ & $16.78 \pm 2.50^{\mathrm{b}, \mathrm{c}, \mathrm{A}}$ & $18.08 \pm 3.24^{\mathrm{c}, \mathrm{A}}$ & $17.87 \pm 1.66^{\mathrm{b}, c, \mathrm{~A}}$ & $16.73 \pm 2.84^{b, c, A}$ & $17.78 \pm 1.99^{\mathrm{b}, c, \mathrm{~A}}$ & $13.49 \pm 0.63^{\mathrm{a}, \mathrm{b}, \mathrm{A}}$ & \multirow[t]{2}{*}{0.057} \\
\hline Judia & $5.93 \pm 0.81^{\mathrm{a}, \mathrm{B}}$ & $13.52 \pm 3.63^{\mathrm{b}, \mathrm{A}}$ & $17.35 \pm 2.06^{\mathrm{b}, \mathrm{c}, \mathrm{A}}$ & $16.49 \pm 2.51^{\mathrm{b}, \mathrm{c}, \mathrm{A}}$ & $15.46 \pm 1.39^{b, c, A}$ & $18.00 \pm 1.59^{\mathrm{c}, \mathrm{A}}$ & $15.76 \pm 2.35^{b, c, A}$ & \\
\hline \multicolumn{9}{|c|}{ ADF (g ADF/100g dry weight) } \\
\hline Longal & $3.72 \pm 0.43^{\mathrm{b}, \mathrm{A}}$ & $3.46 \pm 0.37^{\mathrm{a}, \mathrm{b}, \mathrm{A}}$ & $3.08 \pm 0.37^{a, b, A}$ & $3.26 \pm 0.40^{a, b, A}$ & $2.93 \pm 0.32^{\mathrm{a}, \mathrm{A}}$ & $3.19 \pm 0.42^{a, b, A}$ & $3.22 \pm 0.34^{\mathrm{a}, \mathrm{b}, \mathrm{A}}$ & \multirow[t]{2}{*}{0.016} \\
\hline Judia & $3.45 \pm 0.30^{\mathrm{a}, \mathrm{b}, \mathrm{A}}$ & $3.23 \pm 0.22^{\mathrm{a}, \mathrm{A}}$ & $3.66 \pm 0.46^{a, b, b}$ & $3.38 \pm 0.33^{a, b, A}$ & $3.22 \pm 0.44^{\mathrm{a}, \mathrm{A}}$ & $4.05 \pm 0.62^{b, B}$ & $3.58 \pm 0.52^{\mathrm{a}, \mathrm{b}, \mathrm{A}}$ & \\
\hline \multicolumn{9}{|c|}{ Total carbohydrates (g carbohydrates $/ 100 \mathrm{~g}$ dry weight) } \\
\hline Longal & $91.0 \pm 0.2^{\mathrm{a}, \mathrm{b}, \mathrm{c}, \mathrm{A}}$ & $90.7 \pm 0.4^{\mathrm{a}, \mathrm{b}, \mathrm{A}}$ & $91.3 \pm 0.3^{\mathrm{c}, \mathrm{A}}$ & $90.8 \pm 0.1^{a, b, c, A}$ & $91.1 \pm 0.3^{b, c, A}$ & $90.8 \pm 0.3^{a, b, A}$ & $90.6 \pm 0.3^{\mathrm{a}, \mathrm{A}}$ & \multirow[t]{2}{*}{$<0.001$} \\
\hline Judia & $89.6 \pm 0.4^{a, b}$ & $89.6 \pm 0.4^{a, b, B}$ & $89.5 \pm 0.2^{a, B}$ & $90.2 \pm 0.4^{b, B}$ & $89.3 \pm 0.3^{a, B}$ & $89.4 \pm 0.2^{a, B}$ & $89.7 \pm 0.2^{a, b, B}$ & \\
\hline \multicolumn{9}{|c|}{ Energetic value (kcal/100g dry weight) } \\
\hline Longal & $412 \pm 0.5^{c, A}$ & $410 \pm 2^{\mathrm{a}, \mathrm{b}, \mathrm{A}}$ & $410 \pm 0.6^{a, b, A}$ & $412 \pm 0.4^{\mathrm{C}, \mathrm{A}}$ & $409 \pm 0.6^{\mathrm{a}, \mathrm{A}}$ & $410 \pm 0.5^{a, b, A}$ & $411 \pm 1^{b, c, A}$ & \multirow[t]{2}{*}{0.003} \\
\hline Judia & $409 \pm 2^{a, B}$ & $408 \pm 2^{\mathrm{a}, \mathrm{A}}$ & $409 \pm 1^{a, B}$ & $407 \pm 2^{a, B}$ & $408 \pm 1^{a, B}$ & $408 \pm 1^{a, B}$ & $409 \pm 1^{a, B}$ & \\
\hline
\end{tabular}

Mean \pm SD with different small letter (a-f) superscripts on the same row are significantly different $(P<0.05)$. Mean \pm SD with different capital letter (A-B) superscripts on the same column are significantly different $(P<0.05)$.

$A D F$, acid detergent fiber; NDF, neutral detergent fiber.

protein contents of $3.97 \pm 0.20$ and $5.43 \pm 0.46 \mathrm{~g}$ protein/ $100 \mathrm{~g}$ dry weight, respectively. The higher protein content in Judia than Longal might support the higher formation of Maillard products during chestnut drying, as previously suggested. Our values are in agreement with those published by Míguelez et al. (2004) (6.02 to $8.58 \mathrm{~g}$ protein/100 g dry weight), Ertürk et al. (2006) (4.88 to 10.87 g protein/ $100 \mathrm{~g}$ dry weight), Pereira-Lorenzo et al. (2006) (4.5 to $9.6 \mathrm{~g}$ protein/100 g dry weight), Borges et al. (2008) (4.87 to $7.37 \mathrm{~g}$ protein/100 g dry matter) and Correia et al. (2009) (4.3 to $5.0 \mathrm{~g}$ protein $/ 100 \mathrm{~g}$ dry weight). Míguelez et al. (2004) refer that differences between varieties may be related to differences in soil type, as soils with a greater amount of schist present higher protein content than granite-based soils.

$\mathrm{ADF}$ and NDF showed small variations along drying; however, generally, no significant differences were observed between 0 and $10 \mathrm{~h}$. Judia showed a lower initial content in NDF than Longal variety. Nevertheless, no significant differences between varieties were observed along drying. Also for $\mathrm{ADF}$, similar results were obtained for both varieties for almost all drying times. Our ADF (3.45 and $3.72 \mathrm{~g} \mathrm{ADF/}$ $100 \mathrm{~g}$ dry weight) and NDF (5.93 and $9.74 \mathrm{~g}$ NDF/100 g dry weight) values were similar to those obtained by Pereira-Lorenzo et al. (2006) (2.3 to $4.5 \mathrm{~g} \mathrm{ADF} / 100 \mathrm{~g}$ dry weight and 9.4 to $28.5 \mathrm{~g} \mathrm{NDF} / 100 \mathrm{~g}$ dry weight) and Borges et al. (2008) (1.89 to $3.15 \mathrm{~g} \mathrm{ADF} / 100 \mathrm{~g}$ dry weight and 13.8 to $24.4 \mathrm{~g} \mathrm{NDF} / 100 \mathrm{~g}$ dry weight).

The level of carbohydrates in chestnuts was high $(91.0 \pm 0.2 \mathrm{~g}$ carbohydrates/100 $\mathrm{g}$ dry weight for Longal and $89.6 \pm 0.4 \mathrm{~g}$ carbohydrates $/ 100 \mathrm{~g}$ dry weight for Judia variety). Our results are a little higher than those published by Ertürk et al. (2006), 75.32 to $86.31 \mathrm{~g}$ carbohydrates/100 g dry weight, for several Turkish chestnut cultivars. Nevertheless, after expressing the results in fresh weight, our results (46.9 g carbohydrates $/ 100 \mathrm{~g}$ fresh weight for Longal and $42.4 \mathrm{~g}$ carbohydrates $/ 100 \mathrm{~g}$ fresh weight for Judia variety) were similar to Barreira et al. (2009) for both varieties (44.1 $\mathrm{g}$ carbohydrates $/ 100 \mathrm{~g}$ fresh weight for Longal and $42.1 \mathrm{~g}$ carbohydrates $/ 100 \mathrm{~g}$ fresh weight for Judia variety). Concerning drying, no significant differences were observed between 0 and $10 \mathrm{~h}$ for each variety. So, carbohydrates degradation was not significant during the drying process, the remaining sugar contents were almost unchanged. However, significant differences between varieties were always found, having Longal variety slight higher values than Judia. 
Concerning energetic value, Judia always presented lower values than Longal but the differences were almost negligible. At the beginning $(0 \mathrm{~h})$, Longal had $212 \mathrm{kcal} / 100 \mathrm{~g}$ while Judia had $193 \mathrm{kcal} / 100 \mathrm{~g}$, similar to those obtained by Barreira et al. (2009) for the same varieties (193 kcal/100 g for Longal and $187 \mathrm{kcal} / 100 \mathrm{~g}$ fresh weight for Judia). Regarding drying, no significant differences were detected in Judia along time. Even though small variations were observed for Longal along drying, the energetic values on a dry basis at $10 \mathrm{~h}$ were identical to that presented at $0 \mathrm{~h}$, indicating only slight changes in the macronutrients along the drying process.

When comparing the energetic value of dried chestnut slices per $100 \mathrm{~g}$ of product $(367 \mathrm{kcal} / 100 \mathrm{~g}$ for both varieties) with other kind of snacks, such as fried peanuts and flavored chips, the former had approximately 32 to $40 \%$ less calories than the other snacks, suggesting it to be a healthy and less caloric substitute. On the other hand, the dried chestnut slices had a similar energetic value to dried apple $(346 \mathrm{kcal} / 100 \mathrm{~g})$. This product was developed by a Portuguese enterprise and it had earned a nutrition award at 2013, being labeled as a healthy snack. The demand of this kind of product has nowadays been increasing due to greater consumer concern with health. Furthermore, we performed a preliminary sensory study where 10-member semi-trained panelists were asked to rate the overall acceptance of the dried sliced chestnuts in a $10-\mathrm{cm}$ nonstructured scale ( 0 means unacceptable and 10 means very acceptable). Good results were obtained with an average \pm standard deviation equal to $7.36 \pm 1.41$.

\section{CONCLUSIONS}

Even though slight differences in moisture content were found at the beginning between Longal and Judia varieties, among other properties, the drying behaviors were similar and the experimental data were well adjusted by Page, twoterm and modified Henderson and Pabis models. This is important from the industrial point of view as not adjustments in the drying process are expected to be necessary for these two varieties, being their drying behaviors also easily predicted. Although color differences were detected after drying at $50 \mathrm{C}$ for $10 \mathrm{~h}$, changes on chestnut macronutrients were generally not observed. The variability between varieties was higher than that observed along drying for each variety. Due to their low caloric and glutenfree contents, dried chestnut slices appear as an excellent substitute to other types of snacks.

\section{ACKNOWLEDGMENTS}

Teresa Delgado acknowledges the Fundação para a Ciência e Tecnologia (FCT) for the financial support through the
PhD grant - SFRH/BD/82285/2011, CIMO through the Project PEst-OE/AGR/UI0690/2014, REQUIMTE through the Project PEst-C/EQB/LA0006/2013 and POCTEP Programa de cooperação Transfronteiriça Espanha - Portugal through the Project RED/AGROTEC - Experimentation network and transfer for development of agricultural and agro industrial sectors between Spain and Portugal.

\section{REFERENCES}

AOAC. 1995. Official Methods of Analysis, 16th Ed., Association of Official Analytical Chemists, Arlington, VA.

ATTANASIO, G., CINQUANTA, L., ALBANESE, D. and DI MATTEO, M. 2004. Effects of drying temperatures on physico-chemical properties of dried and rehydrated chestnuts (Castanea sativa). Food Chem. 88, 583-590.

BARREIRA, J.C.M., CASAL, S., FERREIRA, I.C.F.R., OLIVEIRA, M.B.P.P. and PEREIRA, J.A. 2009. Nutritional, fatty acid and triacylglycerol profiles of Castanea sativa Mill. cultivars: A compositional and chemometric approach. J. Agric. Food Chem. 57, 2836-2842.

BORGES, O., GONÇALVES, B., SOEIRO DE CARVALHO, J.L., CORREIA, P. and SILVA, A.P. 2008. Nutritional quality of chestnut (Castanea sativa Mill.) cultivars from Portugal. Food Chem. 106, 976-984.

CECCHINI, M., CONTINI, M., MASSANTINI, R., MONARCA, D. and MOSCETTI, R. 2011. Effects of controlled atmospheres and low temperature on storability of chestnuts manually and mechanically harvested. Postharvest Biol. Technol. 61, 131-136.

CLETUS, A.B. and CARSON, J.K. 2008. Drying curves and apparent diffusivity of New Zealand chestnut variety " 1015 ". J. Food Eng. 85, 381-386.

CORREIA, P. and BEIRÃO-DA-COSTA, M.L. 2012. Effect of drying temperatures on starch-related functional and thermal properties of chestnut flours. Food Bioprod. Process. 90, 284-294.

CORREIA, P., LEITÃO, A. and BEIRÃO-DA-COSTA, M.L. 2009. The effect of drying temperatures on morphological and chemical properties of dried chestnuts flours. J. Food Eng. 90, 325-332.

DELGADO, T., PEREIRA, J.A., BAPTISTA, P., CASAL, S. and RAMALHOSA, E. 2014. Shell's influence on drying kinetics, color and volumetric shrinkage of Castanea sativa Mill. fruits. Food Res. Int. 55, 426-435.

ERTÜRK, Ü., MERT, C. and SOYLU, A. 2006. Chemical composition of fruits of some important chestnut cultivars. Braz. Arch. Biol. Technol. 49, 183-188.

FAO. 2003. Food energy - Methods of analysis and conversion factors. in: FAO (Ed.), Food and Nutrition Paper 77. Rome, pp. 12-14.

GOERING, H.K. and VAN SOEST, P.J. 1970. Forage Fiber Analyses - Apparatus, Reagents Procedures, and Some Applications, Agricultural Research Service - United States Department of Agriculture, Washington, DC. 
GUINÉ, R.P.F. and FERNANDES, R.M.C. 2006. Analysis of the drying kinetics of chestnuts. J. Food Eng. 76, 460-467.

KOYUNCU, T., SERDAR, U. and TOSUN, I. 2004. Drying characteristics and energy requirement for dehydration of chestnuts (Castanea sativa Mill.). J. Food Eng. 62, 165-168.

MENDES DE VASCONCELOS, M.C.B., BENNETT, R.N., ROSA, E.A.S. and FERREIRA-CARDOSO, J.V. 2009. Industrial processing effects on chestnut fruits (Castanea sativa Mill.). 2. Crude protein, free amino acids and phenolic phytochemicals. Int. J. Food Sci. Technol. 44, 2613-2619.

MÍGUELEZ, J.D.L.M., BERNÁRDEZ, M.M. and QUEIJEIRO, J.M.G. 2004. Composition of varieties of chestnuts from Galicia (Spain). Food Chem. 84, 401-404.

MOREIRA, R., CHENLO, F., CHAGURI, L. and VÁZQUEZ, G. 2005. Mathematical modelling of the drying kinetics of chestnut (Castanea sativa Mill.). Influence of the natural shells. Food Bioprod. Process. 83, 306-314.

MOREIRA, R., CHENLO, F., CHAGURI, L. and FERNANDES, C. 2008. Water absorption, texture, and color kinetics of air-dried chestnuts during rehydration. J. Food Eng. 86, 584-594.

MOREIRA, R., CHENLO, F., CHAGURI, L. and MAYOR, L. 2011. Analysis of chestnut cellular tissue during osmotic dehydration, air drying and rehydration processes. Drying Technol. 29, 10-18.

MOREIRA, R., CHENLO, F., TORRES, M.D. and RAMA, B. 2013. Influence of the chestnuts drying temperature on the rheological properties of their doughs. Food Bioprod. Process. 91, 7-13.

PEREIRA-LORENZO, S., RAMOS-CABRER, A.M., DÍAZ-HERNÁNDEZ, M.B., CIORDIA-ARA, M. and RÍOS-MESA, D. 2006. Chemical composition of chestnut cultivars from Spain. Sci. Hortic. (Amsterdam) 107, 306-314.

RAJASEKAR, D., AKOH, C.C., MARTINO, K.G. and MACLEAN, D.D. 2012. Physico-chemical characteristics of juice extracted by blender and mechanical press from pomegranate cultivars grown in Georgia. Food Chem. 133, 1383-1393.

TOGRUL, I.T. and PEHLIVAN, D. 2003. Modelling of drying kinetics of single apricot. J. Food Eng. 58, 23-32.

YALDÝZ, O. and ERTEKÝN, C. 2001. Thin layer solar drying of some vegetables. Drying Technol. 19, 583-597.

ZHANG, M., CHEN, H. and ZHANG, Y. 2011. Physicochemical, thermal, and pasting properties of Chinese chestnut (Castanea mollissima BI.) starches as affected by different drying methods. Starch-Stärke 63, 260-267. 